\title{
The Strategy of Character Education Instilment in SDIT Az-Zahra Sragen
}

\author{
Munif Rofi'atur Rohmah ${ }^{1}$, Husaini Usman ${ }^{2}$ \\ \{rofiatur06@gmail.com ${ }^{1}$, husainiusman@gmail.com ${ }^{2}$ \} \\ Education Management, Postgraduate Program, Universitas Negeri Yogyakarta, Indonesia ${ }^{1,2}$
}

\begin{abstract}
This research aims to understand the strategies applied in the instilment of character education in SDIT Az-Zahra Sragen. The research is carried out using a qualitative approach. The data-collecting techniques used in this research are observation, interview, and documentation. article aims to understand the strategy of character education instilment efforts in SDIT Az-Zahra Sragen. The research shows that character education strategies in SDIT Az-Zahra Sragen are applying breeding activities, the hope of these accustomed activities so that students have a right attitude and get used to it in the school environment, families, and communities; creating character program consisting of clean character and neat, polite, well-mannered, and discipline; forming school officers such as School Health Officers, School Attitude Officers, Love Prayer Officers, and Love Book Officers.
\end{abstract}

Keywords: Strategy, Character Education, Breeding Activities.

\section{Introduction}

The instilment of character education in students will be one of the primary duties constantly shouldered by parents and teachers. Concerning this, a specially designed environment plays a significant role in supporting the completion of character education instilment. For example, the school environment atmosphere that promotes a clean character's formation will make it easier for students to have a clean character. It also can be applied toward student character problems resulting from the wrong environment. Just as the delinquency of students occurred in the elementary school in Pulau Rimau which is one of the causes is lacking the supportive environment to create the character of students especially while at home. As for the delinquency, which the previous researcher found in this elementary school include: hiding friend's stationery, asking friend's pocket money, fighting, being absence school without permission or explanation, lying, calling a friend's name by the name of his or her parents, etc. [1].

Character education is an effort to guide human behavior toward normative standards. The effort also gives way to appreciate the perception of personal values manifested at school. The focus of character education is on ethical purposes, but the field's practice includes strengthening essential abilities amplification following students' social development. Character education not only teaches what is right and what is wrong, but more than that, namely instilment a habit of the good so that students can understand, feel, and have willing to do it [2]. From an intense instilment of habit involving the cognitive aspects, affective, and psycho-motorist of a student, the accumulation of good habits slowly becomes a student's 
strong character. If good habits become a character, it can quickly be done by students without a second thought. In the future, these mannered students will become part of succeeding generations that contribute positively to the nation and country. Character education should fit into every aspect of the classroom's teaching activities, daily practice of school life and integrated with every school's extracurricular activity. Therefore, each student is expected to be able to apply it in their home and surroundings. All aspects of education from the classroom to home should remain ongoing in maintaining educational character values [3].

The urgency of raising the problem into scientific research is in addition the education aimed to shape students have good character as well as the education requires systematizing and integrated effort that must be fully realized by all the components of schools such as teachers, policymakers, parents, and students. The positive effect of raising this research is in order to be known the strategy of character education applied in the school as the site of research. While the negative effect of not raising this study is the other schools cannot learn and adopt the character education strategy applied in the school in this study.

Integrated Islamic Primary School (SDIT) Az-Zahra Sragen, Central Java, Indonesia, is one of The Integrated Islamic Primary School that implements character education programs. The importance of researching the strategy of character education instilment in SDIT AzZahra Sragen is because, in addition to SDIT Az-Zahra as Sragen's Integrated Islamic Primary School pioneer, it also has an integrated character instilment from the curriculum and daily practice whether when students are in the school or at home. So that, this article aims to understand the strategy of character education instilment efforts in SDIT Az-Zahra Sragen.

\section{Method}

The study uses a qualitative research method. The study was conducted in SDIT Az-Zahra Sragen, located in Sragen District, Sragen Regency, Central Java, Indonesia. The data sources in this study are the principal, teacher, and parents of students in SDIT Az-Zahra Sragen. The data-collecting techniques used in this study are interview, observation, and documentation. The data collecting is done with interviews with the school principal, teachers, and students' parents and then reinforced by observation and documentation. Data analysis measures include (1) data reduction, which is data grouping process that corresponds with the focus of the research goal; (2) data display, namely data is presented in the text narratively in the form of a brief description of character education instilment strategy in SDIT Az-Zahra Sragen; (3) conclusion drawing based on the presented data.

\section{Result and Discussion}

\subsection{The Strategy of Character Education Instilment in SDIT Az-Zahra Sragen}

\subsubsection{Applying Breeding Activities}

The process of a breeding character in SDIT Az-Zahra Sragen is held at the beginning of the school year. In a full week, students are taught breeding while in school. The concept of breeding is teaching breeding activities should be done when students are in school. The 
concept of breeding character includes the first, students must say salam when coming to school with a smile then sniff at teachers' hand, the second, students must take off shoes and put on a shoe rack and so on when they enter to the classroom. Besides that, students are also taught ethics in the teachers' office, in the mosque, in the toilet, etc.

The purpose of the breeding activities in SDIT Az-Zahra Sragen is to introduce students to how to behave when they are in the school and make the school one of the places to do the breeding. This breeding is done through school learning, and then students can also do it both at home and in the community. In order to instill character education contained of moral values which is included in the realm of affection, breeding has a crucial role. Because values cannot be taught, values can only be practiced. It is such emphasized by Abdul Rohman [4].

While at home, the supervising character activity model is with the supervision and monitoring by students' parents. Parents are obliged to monitor the children's character activities by the school character checkbook. According to Supraptiningrum and Agustini, besides knowing more about children's character, the supervision is less likely to be minimized lousy character because of total parental supervision [5]. Based on Agus Setiawan's opinion, the school effort to involve parents in instilment character education is the right thing to do by the school. It causes parent or family is one of the components of the educational network besides school and community as a broader environment [6]. Then the more important according to Cut Zahri is that the role of the parent is a very big and lasting influence because the parent and child relationships last a life time, it can't be broken by anyone or any cause. In other words, parent and child relationship is a significant special relationship [7].

As for the hope of that breeding, students can carry it out as well when they are in the home and the community. The breeding of characteristics in the small environment, such as in school and home, as Wolfgang and Marvin emphasized, can later be applied to domestic life as the basis for social, emotional competence in self-management and the social competence needed in practical social life [8].

\subsubsection{Creating Character Program}

The efforts done by SDIT Az-Zahra Sragen to instill character in students is by forming a character team. The character team handles the principal character to be presented and impressed upon the students. The way to instill such characters is: 1) Creating character slogans pasted around a school environment; 2) Always presenting the characters should be done in school ceremony and classroom. According to Sudrajat, the attachment of character slogans in the school environment is a form of reinforcement of school's high-priority character values. Such an environmental setting could support for the shaming of good deed's atmosphere in school life [9].

The characters consist of clean character and neat, polite, well-mannered, and discipline. The method used to teach the character is by giving examples. This character program is also included in the Lesson Plan. For example, based on the teacher's standard is to begin a lesson must be clean and neat, then close learning must also be clean and neat. Character programs in SDIT Az-Zahra Sragen hope that all teachers, administrators, and students in SDIT Az-Zahra Sragen can show an excellent example following character programs already applied in the school. This character program is also expected that students will eventually become clean, neat, polite, well-mannered, and disciplined individuals. 
The school environment should support the development of character education by creating such a situation and an appropriate learning environment for students. Learning is more emphasized in active learning and more effectively in developing of students' basic ability and implementing students' discipline in elementary school [10]. Character education program implemented in the school should get support from various components, because basically the character education will achieve optimal result if it is supported by families, schools, and society [11].

This applicable and repeated character program in SDIT Az-Zahra Sragen will form a firmly embedded school system, especially in a school environment, if parents, teachers, and policyholders commit and work together to promote students' to manifest character education values in their daily lives [12]. In shaping students' character, the character that will be shaped must be repeated. For example, shaping the student's disciplined character. The character of discipline will be shaped when the students repeat it. If done repeatedly, then the student will get used to having disciplined behavior [13].

In more detail, the school system will be imprinted throughout the school community, especially teachers and students, if it is presented continuously and done. Parents who have the duty of supervising their children after school have likewise done much to reinforce the school system. Outside the school environment, schools will be known to the public as a school of such character values that it will indirectly become the appeal of other parents to send their children to SDIT Az-Zahra Sragen.

\subsubsection{Forming School Officers}

These school officers in SDIT Az-Zahra Sragen are formed at the beginning of the school year. Then, in the first week of it, the class board structure selection is also to be done. Names of the classes in SDIT Az-Zahra Sragen use the Islamic State names, and the chief of the class is called class president. That makes the class unique. Students who are not selected in the class board will become school officers. In each class, the school officers consist of two boys and two girls. School officers formed in SDIT Az-Zahra Sragen are School Health Officers, School Attitude Officers, Love Prayer Officers, and Love Book Officers. The purpose of creating school officers in SDIT Az-Zahra Sragen is to teach children students to be honorable, responsible, and to be motivated to keep their good and spread the good on to other friends.

School officials who take from students are an effort of very useful character instilment. This is because students will learn directly and feel their means to be a mandate and responsible when getting the duties. From here, it is understandable that the instilment of character education in SDIT Az-Zahra Sragen is in the level of realization stage. Essentially, this character education realization is the most core activity of character instilment efforts [14]. Through the character education, students are expected to be able to independently improve and use their knowledge, assess, internalize, and personalize the noble character and moral values so that they can manifest in everyday behavior [15].

School officers in SDIT Az-Zahra Sragen are taken from $4^{\text {th }}$ grade students and $5^{\text {th }}$. The companion is from $6^{\text {th }}$ grade. In the meantime, $1^{\text {st }}$ grade students, $2^{\text {nd }}$, and $3^{\text {rd }}$ become the participants. The school officials officiated according to a set schedule. The School Health Officers are on duty to check the students' health/hygiene in the classroom. The School Attitude Officers are on duty to keep students' attitude order. The Love Prayer Officers have the duty of organizing students while praying in the mosque into order. The Love Book Officers have the duty of modeling other students to love reading books and visiting the 
library. The goal of creating school officers in SDIT Az-Zahra Sragen is to improve students' attitudes for the better.

In principle, the implementation of strategy character education values toward students' school is not strictly regulated. However, the important is how character values are understood, embedded, and expected to become permanent behavior in each student [16]. As the above description, SDIT Az-Zahra Sragen is a primary school that implements a character education strategy to the field's level of execution mechanisms. Such real efforts will undoubtedly open more significant opportunities for instilling character education in students.

\section{Conclusion}

Based on the above research, it could be concluded that strategy character education instilment in SDIT Az-Zahra Sragen, namely: 1) applying breeding activities. The purpose of breeding activities is for the school to be one of the places to do breeding and hope students can also do it both at home and in the community; 2) creating a character program. The school's applied character consists of clean character and neat, polite, well-mannered, and discipline; 3) forming school officers. School officers formed in SDIT Az-Zahra Sragen are School Health Officers, School Attitude Officers, Love Prayer Officers, and Love Book Officers. The purpose of forming school officers is to teach students to be honorable, responsible, and motivated to keep their good and spread the good on to other friends.

\section{References}

[1] Sumani, "Upaya Guru dalam Menangani Perilaku Kenakalan Siswa SD," in Prosiding Seminar Nasional Pendidikan Program Pascasarjana Universitas PGRI Palembang, 2019, pp. 909-917.

[2] E. Rohendi, "Pendidikan Karakter di Sekolah," Eduhumaniora J. Pendidik. Dasar, vol. 3, no. 1, pp. 1-9, 2011, [Online]. Available: https://www.golder.com/insights/block-caving-a-viablealternative/.

[3] D. Gularso and K. A. Firoini, "Pendidikan Karakter melalui Program Pembiasaan di SD Islam Terpadu Insan Utama Bantul Yogyakarta,” Trihayu J. Pendidik. Ke-SD-an, vol. 2, no. 2, pp. 19 $25,2016$.

[4] A. Rohman, "Pembiasaan Sebagai Basis Penanaman Nilai-Nilai Akhlak Remaja," Nadwa, vol. 6, no. 1, p. 155, 2016, doi: 10.21580/nw.2012.6.1.462.

[5] Agustini and Supraptiningrum, "Membangun Karakter Siswa Melalui Budaya Sekolah Di Sekolah Dasar," J. Pendidik. Karakter, vol. 5, no. 2, pp. 219-228, 2015, doi: 10.21831/jpk.v0i2.8625.

[6] A. Setiawan, "Prinsip Pendidikan Karakter Dalam Islam (Studi Komparasi Pemikiran AlGhazali dan Burhanuddin Al-Zarnuji)," Din. Ilmu, vol. 14, no. 1, pp. 1-12, 2014.

[7] C. Z. Harun, "Manajemen Pendidikan Karakter," J. Pendidik. Karakter, vol. 3, no. 3, pp. 302308, 2013, doi: 10.32678/tarbawi.v4i02.1230.

[8] W. Althof and M. W. Berkowitz, "Moral Education and Character Education: Their Relationship and Roles in Citizenship education," J. Moral Educ., vol. 35, no. 4, pp. 495-518, 2006, doi: 10.1080/03057240601012204.

[9] A. Sudrajat, "Mengapa Pendidikan Karakter?," J. Pendidik. Karakter, vol. 1, no. 1, pp. 47-58, 2011, doi: 10.21831/jpk.v1i1.1316.

[10] S. Ratnaningsih, "Character Education In Primary School Students Prepare to Face Challenges of The 21st Century," in International Conference on Ethics in Governance: Advance in Social 
Science, Education, and Humanities Research, 2017, no. January 2017, pp. 48-53, doi: 10.2991/iconeg-16.2017.12.

[11] P. Anggraini and T. Kusniarti, "The Implementation of Character Education Model Based on Empowerment Theatre for Primary School Students," J. Educ. Pract., vol. 7, no. 1, pp. 26-29, 2016, [Online]. Available: https://files.eric.ed.gov/fulltext/EJ1089767.pdf.

[12] A. Agboola and K. C. Tsai, "Bring Character Education into Classroom," Eur. J. Educ. Res., vol. 1, no. 2, pp. 163-170, 2012, doi: 10.12973/eu-jer.1.2.163.

[13] M. I. Kurniawan, "Mendidik untuk Membentuk Karakter Siswa Sekolah Dasar: Studi Analisis Tugas Guru dalam Mendidik Siswa Berkarakter Pribadi yang Baik," J. Pedagog., vol. 4, no. 2, pp. 121-126, 2015, doi: 10.21070/pedagogia.v4i2.14.

[14] Haryanto and Akhirin, "Building Students' Character through Integrated Teaching Learning Activities at Madrassa," in International Conference -Internationalization of Islamic Higher Education Institutions Toward Global Competitiveness, 2018, pp. 518-526, [Online]. Available: http://jurnal.unissula.ac.id/index.php/bksptis/article/view/3617.

[15] R. Putry, "Nilai Pendidikan Karakter Anak di Sekolah Perspektif Kemendiknas," Gend. Equal. Int. J. Child Gend. Stud., vol. 4, no. 1, pp. 39-54, 2018, doi: 10.22373/equality.v4i1.4480.

[16] Murniyetti, Engkizar, and F. Anwar, "Pola Pelaksanaan Pendidikan Karakter terhadap Siswa Sekolah Dasar," J. Pendidik. Karakter, vol. 6, no. 2, pp. 156-166, 2016, doi: 10.21831/jpk.v6i2.12045. 